\title{
The groundwater quality of Aruba, Bonaire and Curaçao: a hydrogeochemical study
}

\author{
M.H.G. van Sambeek ${ }^{1}$, H.G.M. Eggenkamp ${ }^{2}$ \& M.J.M. Vissers ${ }^{3}$ \\ ${ }_{1}$ Corresponding author; DHV Milieu en Infrastructuur, P.O. Box 1150, 6801 BD \\ ARNHEM, the Netherlands; e-mail: Mike.vanSambeek@dhv.nl \\ 2 Utrecht University, Institute of Earth Sciences, P.O. Box 80021, 3508 TA UTRECHT, \\ the Netherlands; e-mail: hanse@geo.uu.nl \\ ${ }^{3}$ Utrecht University, Institute of Earth Sciences, P.O. Box 80021, 3508 TA UTRECHT, \\ the Netherlands
}

Manuscript received: 5 February 2000; accepted in revised form: 9 June 2000

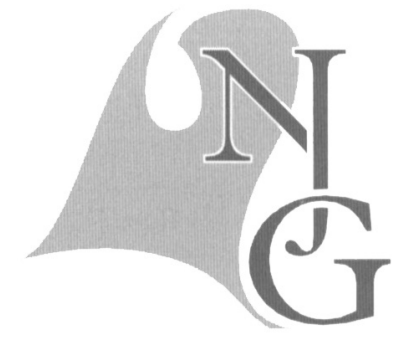

\begin{abstract}
Groundwater resources on the Caribbean Islands of Aruba, Bonaire and Curaçao are limited and of poor quality. The groundwater of the islands is brackish, due to both seawater mixing and the semi-arid climate of the islands. Two hundred and thirty water samples were collected to relate chemical variations in the groundwater of the three islands to the underlying differences in geology, and to define the natural versus anthropogenic influences. Both the chemical and isotopic $(\delta 180, \delta D$, and $\delta 37 \mathrm{Cl}$ ) compositions of samples were determined.

Several geochemical processes are recognised in the chemistry of the groundwater samples. The most important processes are calcite dissolution, cation exchange, silicate weathering and potassium fixation. In (sub) urban areas anthropogenic influences affect the groundwater quality: high nitrate concentrations were measured. Infiltrating domestic and agricultural (waste)water replenishes the aquifer, and has a desalinization effect on the groundwater quality. This phenomenon is primarily seen on Curaçao, the most populated island.

Oxygen and hydrogen isotopic compositions of groundwaters from Curaçao and Bonaire show that the samples are either meteoric water, or are affected by evaporation or seawater mixing. No distinction could be made between the last two processes. Only a few samples were measured for the $\mathrm{Cl}$-isotope composition; all showed that no physical processes have taken place.
\end{abstract}

Keywords: geochemistry, groundwater, isotopes, Netherlands Antilles

\section{Introduction}

The groundwater resources of the semi-arid Leeward Islands, Aruba, Bonaire and Curaçao (Fig. 1), are limited, and are mostly brackish. The limited supply and poor quality of groundwater and the lack of fresh surface water on the Leeward Islands incited the shift towards the production of drinking water through distillation of seawater. In many countries, the groundwater is of extreme importance for society and the quality is closely monitored (Frapporti, 1994). In the Leeward Islands this need is possibly not as great, although a geochemical appraisal of the groundwater composition is still relevant.
The first surveys were held between 1975 and 1980 (Rowbottom \& Winkel, 1979a,b,c), as a follow-up on the study carried out by Grontmij \& Sogreah (1968). The analytical program was limited to some major components. Rowbottom \& Winkel (1979a,b,c) reported that the groundwater composition is mainly determined by intrusion of seawater, sea spray, infiltration of sewage, and irrigation. In the densely populated areas, the chloride concentration was found to be decreasing due to the infiltration of sewage water. The Department of Agriculture and Fisheries (DLVV) was conscious of the problem that careless groundwater management affects suitable groundwater resources, and set up a monitoring network for 


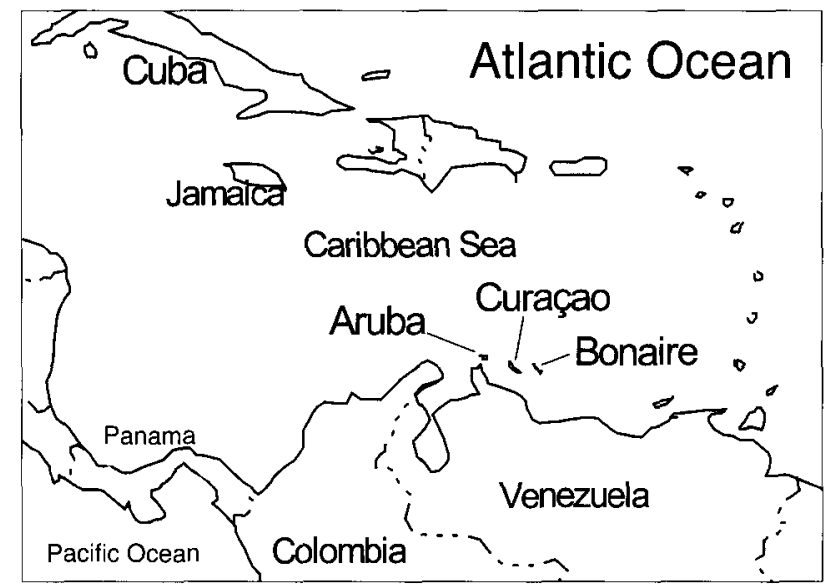

Fig. 1. Position of the Caribbean islands Aruba, Curaçao and Bonaire relative to the mainland of South America.

Curaçao in 1977, to be able to determine changes in groundwater tables and groundwater quality. They also set up a monitoring network for the islands of Bonaire and Aruba in 1979. In contrast to the monitoring on Curaçao, which is still operational, the monitoring on Bonaire and Aruba declined after a short period.

The present contribution reports on surveys that were held between 1991 and 1994 (Louws \& Bruine, 1992; Linsen \& Van Sambeek, 1995). The analytical package is more comprehensive than in the earlier surveys. For Curaçao, Louws et al. (1997) had evaluated the data and compared the results with those of the earlier surveys. We compare the water chemistry of the three islands and its dependence on geological and geographical features, and interpret the chemical and isotopic data from the surveys.

\section{Geography, climate and land use}

The islands are located north of Venezuela, in the Caribbean Sea (Fig. 1). Table 1 overviews some relevant geographical data on the three islands. The climate is semi-arid and only a small amount of the precipitation reaches the groundwater. The average yearly temperature is $27.5^{\circ} \mathrm{C}$. Rainfall is extremely vari-

Table 1. Geographical data on Aruba, Bonaire and Curaçao.

\begin{tabular}{lrrr}
\hline & Aruba & Curaçao & Bonaire \\
\hline surface area $\left(\mathrm{km}^{2}\right)$ & 193 & 444 & 288 \\
length $(\mathrm{km})$ & 30 & 64 & 40 \\
width $(\mathrm{km})$ & 5.5 & 16 & 12.5 \\
highest altitude $(\mathrm{m})$ & 189 & 372 & 241 \\
population & 69,000 & 152,000 & 14,200 \\
population density $\left(\mathrm{km}^{-2}\right)$ & 360 & 341 & 49 \\
capital & Oranjestad & Willemstad & Kralendijk \\
inhabitants of capital & 16,000 & 43,600 & 2,000 \\
& & & \\
\end{tabular}

able, with an annual average of $580 \mathrm{~mm}$. The scanty vegetation of cactus and thorn-bushes is not a consequence of the dry climate but rather a result of the clearing of woods in the early sixteenth century during the Spanish and Dutch occupation, and of overexploitation of the islands in the period that followed (Westermann \& Zonneveld, 1956).

Nowadays, agriculture on the islands is concentrated on Curaçao and is limited to a few small areas. In the past, however, there were agricultural activities to a somewhat larger scale in the form of plantations and terraced land. The decline of agriculture was mainly caused by the development of industry, in particularly the refineries, and tourism.

\section{Geology and geohydrology}

Curaçao, Aruba and Bonaire are situated at the boundary of the Caribbean and South-American plates and their Cretaceous and Early Tertiary geology reflects the movement along this boundary. The basement of the islands is formed by a strongly folded succession of volcanics and sediments of Cretaceous and Early Tertiary age, which in places - particularly on Aruba - has been intruded by dioritic magma. The igneous rocks of the islands indicate that they formed as part of a volcanic arc that was situated on the leading edge of a plate moving into the Caribbean from the west (Pacific Ocean). At the end of the Cretaceous, this island arc was thrust against the protruding parts of the northern margin of the South-American continent. This collision and the subsequent uplift of the continental margin in the Early Tertiary caused the folding, faulting and metamorphism of the rocks on the islands. On Aruba, the basic volcanics are intruded by a quartz diorite; on Bonaire, the volcanic core is made up of the Washikemba Formation, which consists of a succession of dacitic-rhyolitic and basaltic-andesitic composition; and on Curaçao, two cores of basic lavas are overlain by the Knip Group, a succession of chert-rich sediments (Beets \& MacGillavry 1977; Herweijer et al., 1977; MacGillavry, 1977; Klaver 1987).

The changes in sea level that occurred during the Quaternary, combined with a slow tectonic rise of the islands, caused the formation of limestone terraces in coastal areas. Unlike on Curaçao and Bonaire, where the terraces can be found along almost the entire coast, the limestones on Aruba occur in rather small, sometimes isolated, patches. The limestone is highly permeable, and karstic phenomena have developed in many places. At some locations, the limestone rests upon the basement of the crystalline rock, and sometimes a deep bed of alternating sand and clay layers 
underlies the limestone. Small aquifers may occur in the sands and clays of the limestone regions that are often saturated with brackish or seawater, especially at sites near the coast (De Buisonjé, 1974).

The volcanic and crystalline rocks are nearly impermeable (Abtmeier, 1978). They may show permeability along fracture lines and in the weathered zone. Rather than a regional system flowing under a regional water-table regime, there is isolated flow through a number of fracture systems where the position of the water table is governed by the geometric and hydraulic characteristics of each system (Grontmij \& Sogreah, 1968). A simplified overview of the geology is given in Figure 2.

\section{Sampling and analyses}

We collected 33 well-water samples from Aruba, 96 from Curaçao, and 98 from Bonaire. This comprised a subset of the wells present on Curaçao, whereas it entailed virtually all suitable wells on the other two islands. All sampled wells are part of the groundwatermonitoring network that had been set up by the DLVV. Two separate samples were taken from each well: one unacidified sample for anion determination and one acidified, filtered $(0.45 \mu \mathrm{m})$ sample for cation determination. Electric conductivity (Ec), $\mathrm{pH}$ and temperature of the water were measured in the field. Cation concentrations were measured by ICP-AES
(Inductively Coupled Plasma - Atomic Emission Spectrometry). Anions were analysed by using ion chromatography. Out of the total set of samples, 8 from Curaçao and 13 from Bonaire were measured for $\delta^{18} \mathrm{O}$ and $\delta \mathrm{D}$. Also, we measured the chlorine isotopic composition of 8 samples from Bonaire.

Table 2 gives the distribution of the sampled wells over the various rock compositions. The differences over the three islands are noteworthy. Most striking is that virtually no wells were sampled in the limestone areas on Curaçao.

\section{Results}

The temperature of the groundwater is generally between $30^{\circ} \mathrm{C}$ and $31^{\circ} \mathrm{C}$. Although concentrations of the major components are highly variable in wells from the various islands, differences between the is-

Table 2. Distribution of the sampled wells over the various rock compositions. On Aruba and Bonaire, most of the available wells were sampled, while only a small subset was sampled on Curaçao.

\begin{tabular}{lcclc}
\hline rock type & Aruba & Curaçao & Bonaire & total \\
\hline volcanics & 9 & 70 & 50 & 129 \\
diorite & 14 & - & - & 14 \\
clastic & - & 23 & - & 23 \\
limestone & 10 & 3 & 48 & 61 \\
total & 33 & 96 & 98 & 227 \\
\hline
\end{tabular}

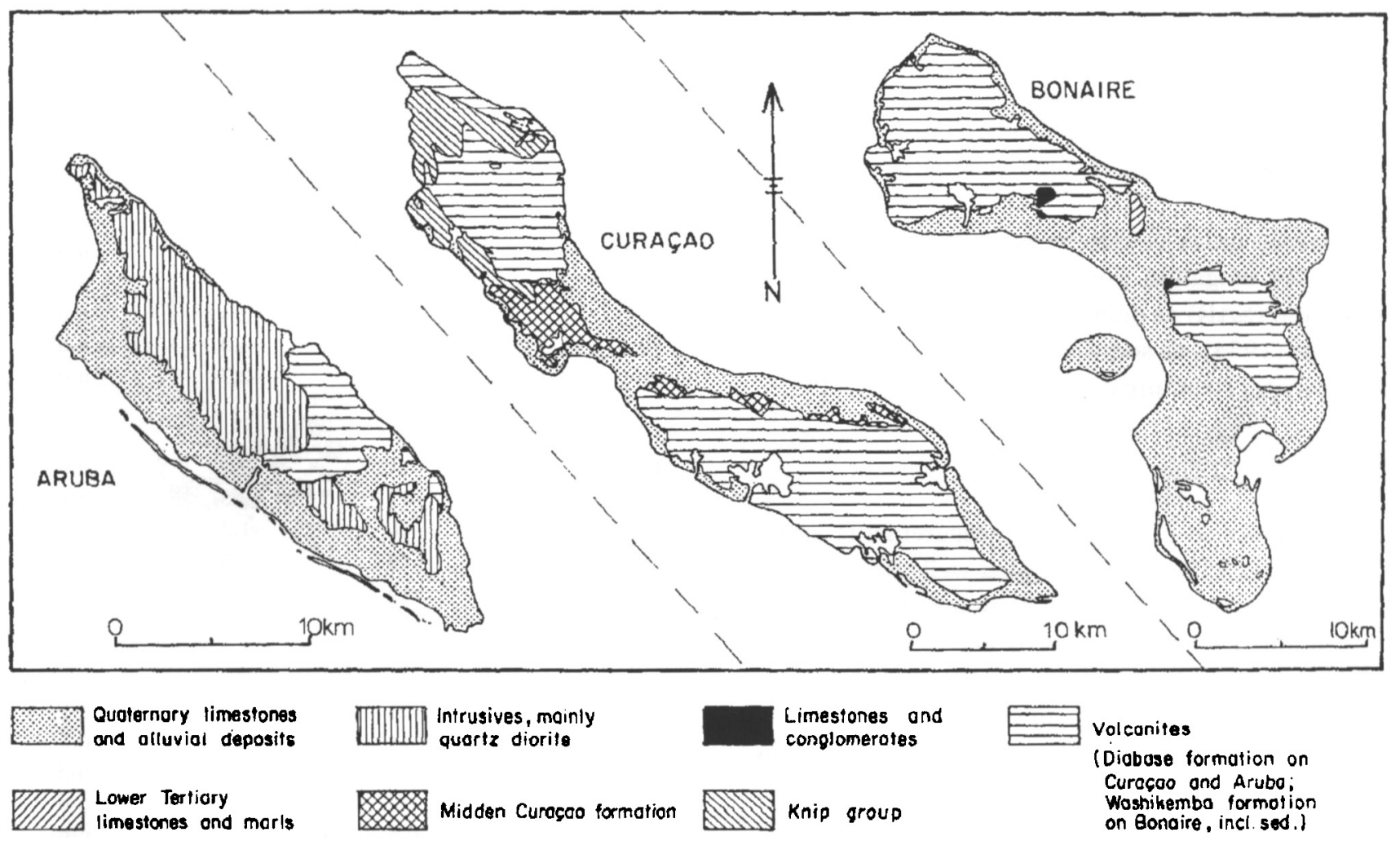

Fig. 2. Geologic sketch maps of Aruba, Curaçao and Bonaire (after Westermann, 1932; Pijpers, 1933; Beets, 1966; Lagaaij, 1968). 
Table 3. Median concentration of the major components in the groundwaters of Aruba, Curaçao en Bonaire, and in the various rock types. All concentrations are in $\mathrm{mg} / \mathrm{l}$ except for the electro-conductivity $(\mathrm{Ec}, \mathrm{mS} / \mathrm{cm}$ ) and the $\mathrm{pH}$. $\mathrm{n}-\mathrm{d}=$ not determined.

\begin{tabular}{|c|c|c|c|c|c|c|c|}
\hline & Aruba & Curacao & Bonaire & volcanic & diorite & clastic & limestone \\
\hline $\mathrm{Ec}$ & 5.7 & 1.9 & 4.3 & 2.2 & 6.1 & 3.1 & 4.7 \\
\hline $\mathrm{pH}$ & 7.8 & 7.3 & 7.8 & 7.5 & 7.9 & 7.1 & 7.8 \\
\hline $\mathrm{Ca}$ & 80 & 120 & 145 & 111 & 70 & 144 & 150 \\
\hline $\mathrm{Mg}$ & 104 & 87 & 95 & 85 & 75 & 103 & 105 \\
\hline $\mathrm{Na}$ & 1060 & 205 & 800 & 268 & 1125 & 544 & 935 \\
\hline $\mathbf{K}$ & 17 & 1.4 & 11 & 2.4 & 15 & 11 & 30 \\
\hline $\mathrm{Cl}$ & 1500 & 425 & 1650 & 527 & 1450 & 949 & 1935 \\
\hline $\mathrm{HCO}_{3}$ & 380 & 455 & 365 & 457 & 455 & 498 & 305 \\
\hline $\mathrm{SO}_{4}$ & 180 & 98 & 185 & 112 & 215 & 295 & 254 \\
\hline $\mathrm{NO}_{3}$ & $n-d$ & 30.6 & 4.6 & 11 & $\mathrm{n}-\mathrm{d}$ & 5.3 & 5.2 \\
\hline
\end{tabular}

lands are evident (see Table 3). The $\mathrm{pH}$ is fairly comparable with values between 6.7 and 8.4. Clear differences are found in the salinity as measured by the Ec on the islands. The $\mathrm{Ec}$ is lowest on Curaçao (median $1.94 \mathrm{mS} / \mathrm{cm})$, and highest on Aruba $(5.7 \mathrm{mS} / \mathrm{cm})$. These trends are found for all major ions, with the exception of $\mathrm{Ca}$ and $\mathrm{HCO}_{3}$.

The speciation and saturation indices of the groundwaters were calculated with the aqueous chemical model, WATEQX (Van Gaans, 1989). Most waters are saturated with quartz, calcite, dolomite and magnesite. Supersaturation is visible in the field from calcite crusts in the soils, wells and pools. The $\mathrm{Ec}$ of groundwater varies between 0.5 and $30 \mathrm{mS} / \mathrm{cm}$. Groundwater shows lower Ec-values in the volcanics than in the limestone formations near the coast. This can be explained by the position of the limestones, which are generally situated at a low altitude near the coast, and by their permeability. Seawater intrusion occurs mainly in the permeable limestones so that groundwater in these regions generally shows higher Ec values.

A useful index to classify the suitability of groundwater for irrigation purposes is the sodium-adsorption ratio (SAR) as defined by U.S. Salinity Laboratory Staff (1954), as sodium-rich water may deteriorate the physical structure of the soil (pore clogging):

$\mathrm{SAR}=\frac{\mathrm{Na}}{\sqrt{\mathrm{Ca}+\mathrm{mg}}}$

With respect to conductivity measurements and the SAR, about $75 \%$ of the sampled wells from Curaçao are suitable for irrigation. In comparison, only $33 \%$ of the sampled wells from Aruba and $30 \%$ of the sampled wells from Bonaire are suitable for this purpose. Where restrictions for irrigation use occur at $\mathrm{Ec}$ over $3 \mathrm{mS} / \mathrm{cm}$, higher Ec values are acceptable for livestock, and moderate restrictions occur only if the conductivity exceeds $8 \mathrm{mS} / \mathrm{cm}$. Suitability for livestock drinking is comparable on all islands and about $85 \%$ of the sampled wells contain water that is suitable for livestock.

Values for $\delta^{18} \mathrm{O}$ are between -4 and $-1 \%$, and $\delta \mathrm{D}$ values between -20 and $-5 \%$; these samples are either on, or to the right of the meteoric water line (Table 4$) ; \delta^{37} \mathrm{Cl}$ values are all $0 \%$ with respect to ocean chloride.

\section{Discussion}

Sea spray, intrusion and rainwater all influence the groundwater composition of Aruba, Bonaire and $\mathrm{Cu}-$

Table 4. Results of the isotope measurements for the water samples from Curaçao and Bonaire. Data from Louws et al. (1997) and Linsen \& Van Sambeek (1995). $8 D$ and $\delta^{18} \mathrm{O}$ are reported relative to V-SMOW, $\delta^{37} \mathrm{Cl}$ relative to SMOC. $\mathrm{n}-\mathrm{d}=$ not determined.

\begin{tabular}{lccc}
\hline sample & $\delta \mathrm{D}$ & $\delta^{18} \mathrm{O}$ & $\delta^{37} \mathrm{Cl}$ \\
\hline Curaçao & & & \\
13 & -8 & -2.1 & $\mathrm{n}-\mathrm{d}$ \\
20 & -10 & -2.2 & $\mathrm{n}-\mathrm{d}$ \\
22 & -10 & -2.0 & $\mathrm{n}-\mathrm{d}$ \\
37 & -7 & -2.0 & $\mathrm{n}-\mathrm{d}$ \\
40 & -8 & -2.2 & $\mathrm{n}-\mathrm{d}$ \\
55 & -7 & -2.4 & $\mathrm{n}-\mathrm{d}$ \\
70 & -16 & -4.0 & $\mathrm{n}-\mathrm{d}$ \\
88 & -11 & -2.7 & $\mathrm{n}-\mathrm{d}$ \\
& & & \\
Bonaire & & & \\
16 & -14 & -2.3 & 0.0 \\
21 & -17 & -2.8 & -0.1 \\
24 & -10 & -1.2 & $\mathrm{n}-\mathrm{d}$ \\
36 & -14 & -2.8 & 0.0 \\
38 & -18 & -3.0 & -0.1 \\
39 & +25 & +4.1 & $\mathrm{n}-\mathrm{d}$ \\
49 & -8 & -1.1 & -0.1 \\
52 & -19 & -3.6 & 0.0 \\
61 & -21 & -4.1 & -0.1 \\
78 & -11 & -1.7 & 0.0 \\
79 & +5 & -1.1 & $\mathrm{n}-\mathrm{d}$ \\
80 & -24 & -4.2 & $\mathrm{n}-\mathrm{d}$ \\
81 & +5 & +0.9 & $\mathrm{n}-\mathrm{d}$ \\
\hline & & & \\
\hline & & &
\end{tabular}


raçao. The composition of rainwater in coastal areas is close to diluted seawater. Therefore, ion ratios in rainwater on the islands should resemble those of the bulk seawater. In scattergrams, where the concentrations of elements are plotted against the chloride content, the groundwater will plot on a seawater reference line (SRL) either as (evaporated) rainwater or as (diluted) seawater. Deviations from this line point to the influence of geochemical processes that took place between rock and groundwater. Geochemical processes that could cause deviations from the ideal seawater-mixing line are chemical weathering, cation exchange, sorption, and pollution. The chemical weathering and cation-exchange processes are closely related to the type of rock that is in contact with the water. A clear difference between the intrusive/volcanic rocks and the limestones is expected.

\section{Cation exchange and sorption}

This difference between the two rock types is evident in the various scattergrams of Figure 3. As limestone has a very low cation-exchange capacity, $\mathrm{Na}, \mathrm{K}$, and $\mathrm{Mg}$ in groundwater from these areas show little devia- tion from the SRL. In the groundwaters deriving from intrusive or volcanic rocks, cation exchange is visible throughout the entire range of groundwater compositions. The most important exchange process occurs due to freshening and salinisation of the groundwater, where sodium and potassium are exchanged for calcium.

The chloride/sodium scatterplot shows that sodium is always enriched in the fresh waters with $\mathrm{Cl}$ less than $300 \mathrm{mg} / 1$, indicating freshening of the aquifer as calcium is replacing sodium on the exchange complex. This also means that the ambient groundwater salinity was higher than $300 \mathrm{mg} / \mathrm{l} \mathrm{Cl}$. Freshening as well as salinisation occurs above this salinity level. Concentrations of potassium may change more than one order of magnitude, and may also be removed in desalinisation water. Potassium is completely removed in some groundwaters in the diabase on eastern Curaçao. These phenomena are caused by fixation of potassium by clays like illite, which occurs as a weathering product of the crystalline rock. In the highly saline waters $(\mathrm{Cl}$ above $10,000 \mathrm{mg} / \mathrm{l})$, sodium and potassium are removed in an equal ratio upon cation exchange with calcium. In these waters, cation exchange is responsi-
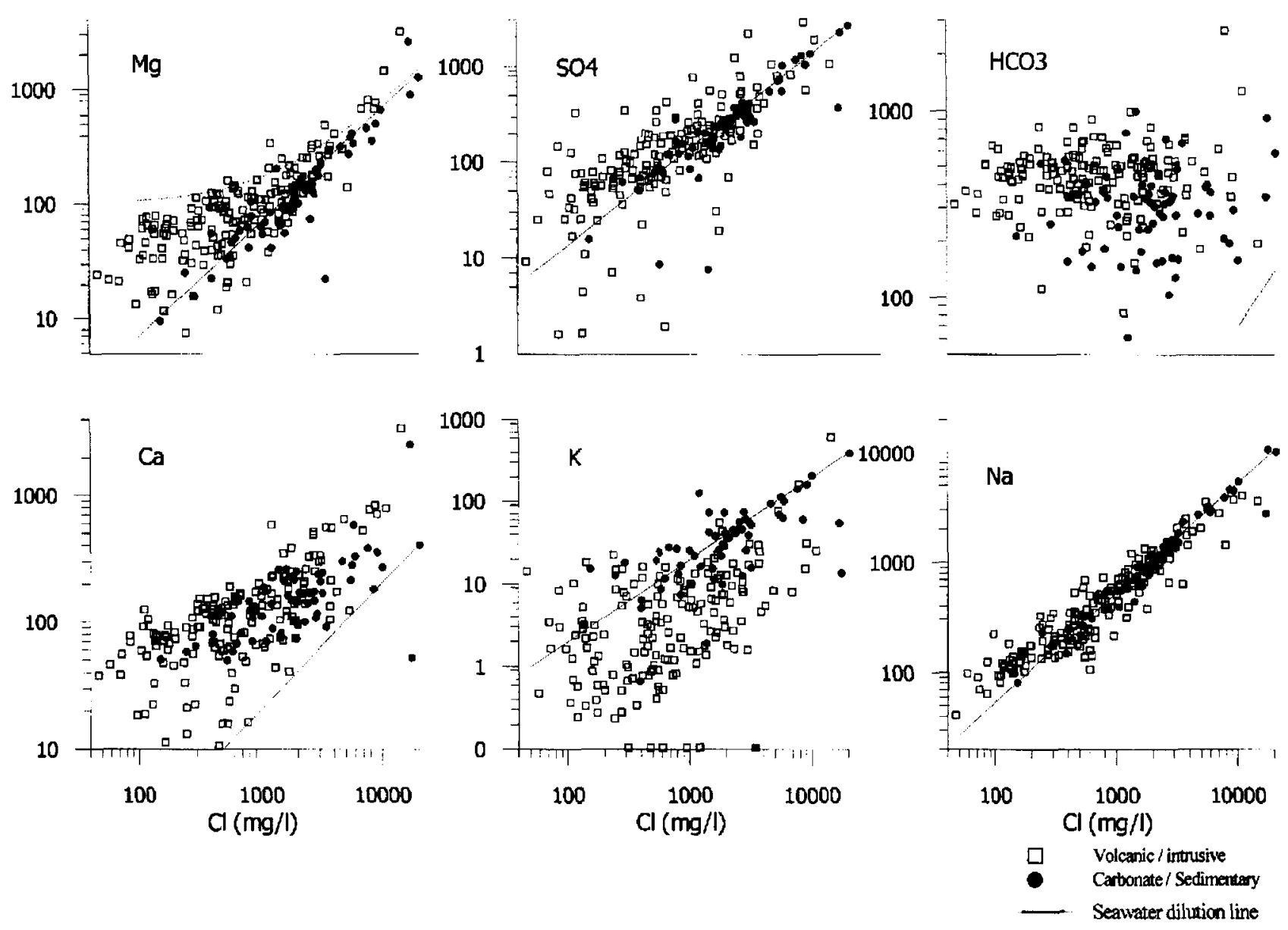

Fig. 3. Scatterplots for the main components of the water samples relative to the chloride content of the samples. Seawater is at the right side of the seawater-dilution line in all plots. 
ble for the increased concentration of calcium, and for the decreased concentrations of sodium and potassium.

\section{Chemical weathering}

Calcium and bicarbonate concentrations are higher in all groundwater samples than expected from the SRL. No difference between limestone and other rocks is found in the samples (Fig. 3). As there are many possible sources of calcium (cation exchange and dissolution of gypsum, calcite or other minerals), and as water taken from the volcanic/intrusive areas may have passed limestone, it is impossible to distinguish between these rock types. Magnesium, however, is released upon weathering of olivines, pyroxenes and hornblende.

Whereas calcium and potassium show broad bands in the log-normal scatterplots (maximum factor of enrichment is 10 upon salinisation through the whole range of salinities), magnesium increases $100 \mathrm{mg} / \mathrm{l}$ at maximum, shown by the dotted line in Figure 3. This indicates that cation exchange is not the process responsible for these increased magnesium concentrations. Silicate weathering also causes significantly higher silica contents in the groundwater derived from crystalline rock, which do not occur in limestone formations. This also holds for manganese, which is a minor constituent in several silicates and absent in the limestone. Strontium, to the contrary, is significantly higher in the groundwater derived from the limestone, indicating that dissolution of limestone is a major contributor.

\section{Pollution}

Aruba samples were not analyzed for nitrate. On the other two islands, nitrate is found in most samples. Concentrations of nitrate above $25 \mathrm{mg} / 1$ (European drinking-water standard) are mainly found in $\mathrm{Cu}-$ raçao, and sometimes in Bonaire. Even concentrations above $100 \mathrm{mg} / \mathrm{l}$, which are sometimes considered to be harmful for livestock (Ayers \& Westcot, 1985), have been measured. It must be mentioned, however, that Berende et al. (1979) showed that much higher nitrate concentrations in milk fed to calves are not harmful. The harmfulness of high nitrate concentrations are thus still in debate.

In many samples, sulphate and potassium also show higher concentrations than expected from the SRL. Pollution is the cause. The disposal of fresh waste or sewage water into the ground by the use of cesspits also has a desalinizing impact on the local groundwater quality in populated areas. Salinity measurements con- firm this. The desalinizing impact of infiltrating waste and sewage water on the local groundwater quality is seen particularly in the suburban areas of Curaçao.

\section{Redox processes}

Curaçao is the only island with sedimentary aquifers. The sedimentary Knip Formation $(3.7 \mathrm{mg} / 1 \mathrm{Fe}$ ) and the Midden Curaçao Formation $(0.7 \mathrm{mg} / \mathrm{l} \mathrm{Fe})$ show significant amounts of iron (other aquifers less than $0.2 \mathrm{mg} / 1 \mathrm{Fe}$ ). Eh values of water from these formations are also very negative. This more reducing environment may be explained by the presence of organic carbon in sedimentary formations. Sulphate concentrations falling far below the SRL level can be explained by sulphate reduction. Although nitrate concentrations are high in these samples, it is easily possible to explain this with recent mixing of polluted water with older water from which sulphate was removed by reduction.

\section{Mineral precipitation}

Waters are often saturated with calcite, dolomite and magnesite. Release of calcium by cation exchange, and of magnesium due to mineral dissolution in combination with high bicarbonate concentrations present in the brackish water, are responsible. Minerals can become saturated in solution and subsequently precipitate also as a result of evaporation.

\section{Isotope composition}

It is generally assumed in groundwater studies that the isotopic composition of water $\left(\delta^{18} \mathrm{O}\right.$ and $\left.\delta \mathrm{D}\right)$ behaves as a conservative property. This indicates that the isotopic composition of the water sample should be the result of mixing various end-members in a specific system. In the situation of the Leeward Islands, the main end-members should be meteoric water and seawater. Due to the high surface temperatures, the isotopic composition of the water will, however, also be influenced by evaporation of the water. The lighter isotopes $\left({ }^{16} \mathrm{O}\right.$ and $\left.{ }^{1} \mathrm{H}\right)$ will preferentially depart from the original water sample during evaporation. This evaporation follows a trend that has a different slope than the meteoric-water line, and that strongly depends on the relative humidity of the air (Gonfiantini, 1986). It follows that the slope of the evaporation line is less at lower than at higher relative humidities, and it changes from about 3.9 at a relative humidity of $0 \%$ to 6.8 at a relative humidity of $95 \%$.

We have plotted $\delta^{18} \mathrm{O}$ values vs. $\delta \mathrm{D}$ values of the water samples in Figure 4. Most samples are not far from the global meteoric-water line, and the effect on 


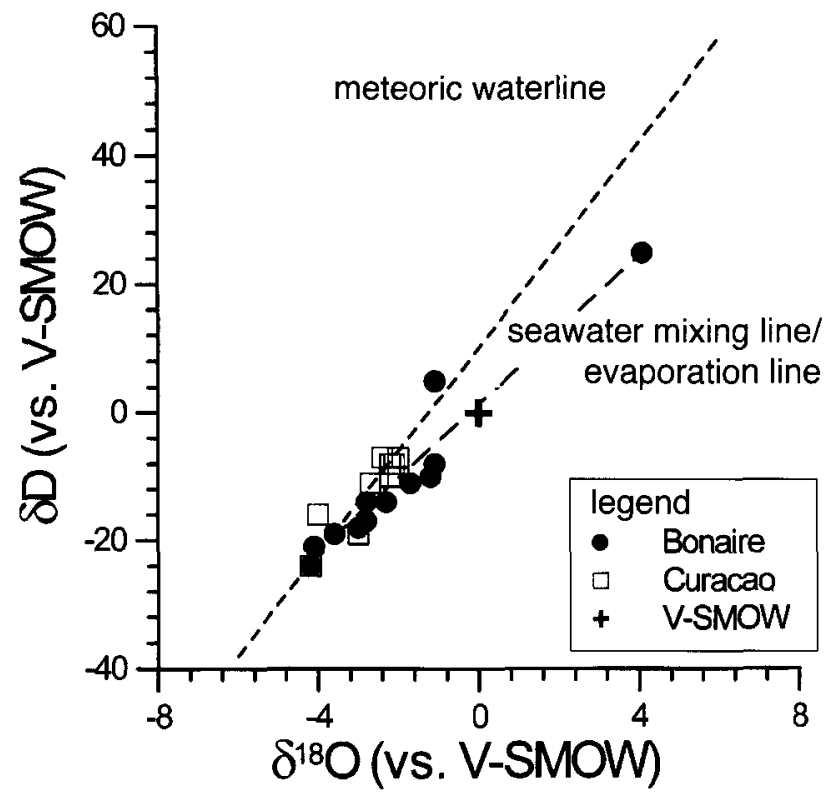

Fig. 4. Plot of $\delta^{18} \mathrm{O}$ vs. $\delta \mathrm{D}$ of the water samples. It is not possible to distinguish between a seawater-mixing line and an evaporation line. Most samples are close to the intersect of the local meteoric-water line and the mixing line with seawater or the line that indicates the evaporation of water samples. This plot shows that it is not possible to distinguish between the processes that have taken place in these samples using solely hydrogen and oxygen isotopes.

the isotopic composition is relatively small, although these samples may be affected by either evaporation or mixing with seawater. A few samples, however, deviate significantly from the global meteoric-water line (Fig. 4). These samples follow a line through the seawater composition, with a slope of approx. 5 . This could be caused by either mixing of meteoric water with seawater, or evaporation of this water in the semi-arid climate of these islands. It is not possible to distinguish between these two processes. The reason is that both processes show the same characteristics in a $\delta^{18} \mathrm{O}$ vs. $\delta \mathrm{D}$ diagram, except for the two samples that are more evaporated than seawater (i.e., that have positive $\delta^{18} \mathrm{O}$ and $\delta \mathrm{D}$ values). Although evaporation may strongly affect the isotope composition of surface water, evaporation will, however, commonly result in only a relatively small increase of the salinity of this water. The influence of evaporation alone can not explain the high salinity of the groundwater. A more important process must be mixing with seawater. If groundwater mixes with seawater, both the salinity and the isotope composition of the mixture will change according to a linear relationship. This relationship holds for most samples for which both the isotopic and the chemical compositions have been determined.

All measured chlorine isotope compositions are equal to those of seawater. As chlorine-isotope ratios are mainly varying due to physical processes (Eg- genkamp, 1994), it is concluded that these physical processes do not play an important role in the distribution of chloride in the groundwater, and that, indeed, seawater intrusion and evaporation are far more important.

\section{Conclusions}

The groundwater of the islands of Aruba, Bonaire and Curaçao is rather brackish, with chloride concentrations varying between $115 \mathrm{mg} / \mathrm{l}$ (fresh water) and $17.000 \mathrm{mg} / 1$ (almost seawater). The main possible salinisation processes of the groundwater are seawater intrusion, the influence of sea spray, and evaporation. A large variety of processes influence the initial groundwater quality. Cation exchange influences sodium, calcium and potassium concentrations. Additionally, potassium is removed through sorption on secondary minerals. Magnesium, manganese and silica enter the groundwater by weathering of minerals. Anthropogenic effects influence concentrations of potassium, sulphate and nitrate. Sulphate is probably removed by sulphate reduction. High nitrate concentrations in these samples are due to recent mixing with polluted (waste)water. These high nitrate concentrations measured in many wells are probably due to the use of cesspits close to these wells. Cesspits have also a desalinizing impact on the local groundwater quality in populated areas.

The isotopic compositions of the samples indicate that most water is of meteoric origin, with some samples that also show either mixing with seawater or excessive evaporation. The precise processes can, however, not be deduced from the isotopic composition, as data fall generally too close together.

\section{Acknowledgements}

The authors would like to thank the local governments of Aruba, Bonaire and Curaçao, the many owners of private wells, DLVV Curaçao and Bonaire, STINAPA, CARMABI, DOW-Curaçao, Notary Mr. A.P. Knuf, KABNA Den Haag, Utrecht University, Billiton International Metals BV, Dienst Gemeentewerken Rotterdam, TNO (IGG) Delft, Iwaco, Fugro and DHV. The studies were initiated by Simon Vriend. Field work on the islands was conducted by Heddy de Wijs, Robbie Louws, Ronald de Bruine and René Linsen.

\section{References}

Abtmeier, B., 1978. Zur Hydrologie der Insel Curaçao, Ph.D. thesis Technische Hochschule Aachen: 178 pp.

Ayers, R.S. \& Westcot, D.W., 1985. Water quality for agriculture. FAO Irrigation and Drainage Paper 29, rev. 1: 174 pp. 
Beets, D.J., 1966. Stratigraphic position and age of a Cretaceous ammonite from Curaçao, Netherlands Antilles. Memoirs of the Faculty of Sciences, Kyushu University D 17: 287-294.

Beets, D.J. \& MacGillavry, H.J., 1977. Outline of the Cretaceous and Early Tertiary history of Curaçao, Bonaire and Aruba. Guide to the field excursions on Curaçao, Bonaire and Aruba. STINAPA: 1-6.

Berende, P.L.M., Terluin, R.W. \& Van der Wal, P., 1979. High doses of nitrate in rations for milk-fed calves. 1. Effect on zootechnical characteristics, methemoglobin formation and nitrate and nitrtie in some organs. Zeitschrift für Tierphysiology, Tierernährung und Futtermittelkunde 42:312-321.

De Buisonjé, P.H., 1974. Neogene and Quaternary geology of Aruba, Curaçao and Bonaire. Natuurwetenschappelijke Studiekring voor Suriname en de Nederlandse Antillen (Utrecht) 78:293 pp.

Eggenkamp, H.G.M., 1994. $\delta^{37} \mathrm{Cl}$; the geochemistry of chlorine isotopes. Geologica Ultraiectina 116:150 pp.

Frapporti, G., 1994. Geochemical and statistical interpretation of the Dutch national ground water quality monitoring network. Geologica Ultraiectina 115:119 pp.

Gonfiantini, R., 1986. Environmental isotopes in lake studies. In: Fritz, P. \& Fontes, J. (eds.): Handbook of environmental isotope geochemistry 2. Elsevier (Amsterdam): 112-168.

Grontmij \& Sogreah, 1968. Water and land resources development plan for the islands of Aruba, Bonaire and Curaçao. Report Grontmij (De Bilt): 133 pp.

Herweijer, J.P., De Buisonjé, P.H. \& Zonneveld, J.I.S., 1977. Neogene and Quarternary geology and geomorphology. Guide to the field excursions on Curaçao, Bonaire and Aruba. STINAPA: 3955.

Klaver, G.Th., 1987. The Curaçao Lava Formation; an ophiolitic analogue of the anomalous thick layer $2 \mathrm{~B}$ of the Mid-Cretaceous oceanic plateaus in the Western Pacific and Central Caribbean. GUA Papers of Geology 27: 168 pp.

Lagaaij, R.A., 1969. Geophysical investigations of the Netherlands Leeward Antilles. Verhandelingen der Koninklijke Nederlandse
Akademie van Wetenschappen, afd. Natuurkunde, Reeks 1, 25: $1-86$.

Linsen, R. \& Van Sambeek, M.H.G., 1995. Geochemical groundwater survey of Bonaire. M.Sc. thesis, Utrecht University: $49 \mathrm{pp}$.

Louws, R.J. \& Bruine, R., 1992. Groundwaters of Curaçao, a geochemical survey. M.Sc. thesis, Utrecht University: 43 pp.

Louws, R.J., Vriend, S.P. \& Frapporti, G., 1997. De grondwaterkwaliteit van Curaçao. Een hydrogeochemisch onderzoek. $\mathrm{H}_{2} \mathrm{O}$ 30: $788-791$

MacGillavry, H.J., 1977. Tertiary formations. Guide to the field excursions on Curaçao, Bonaire and Aruba. STINAPA: 36-38.

Pijpers, P.J., 1933. Geology and paleontology of Bonaire (D.W.I.). Geographische en Geologische Mededeedelingen, Physiographisch-Geologische reeks 8: 1-101.

Rowbottom, R.J. \& Winkel, C.W., 1979a. Well survey Aruba. Department of Agriculture Curaçao: $38 \mathrm{pp}$.

Rowbottom, R.J. \& Winkel, C.W., 1979b. Well survey Bonaire. Department of Agriculture Curaçao: $42 \mathrm{pp}$.

Rowbottom, R.J. \& Winkel, C.W., 1979c. Groundwater investigation Curaçao. Department of Agriculture Curaçao: 73 pp.

U.S. Salinity Laboratory Staff, 1954. Diagnosis and improvement of saline and alkali soils. U.S. Department of Agriculture Handbook 60: $160 \mathrm{pp}$.

Van Gaans, P.F.M., 1989. WATEQX - a restructured, generalized and extended FORTRAN 77 computer code and database format for the WATEQ aqueous chemical model for element speciation and mineral saturation, for use on personal computers or main frames. Computers and Geosciences 15: 843-887.

Westermann, J.H., 1932. The geology of Aruba. Geographische en Geologische Mededeedelingen, Physiographisch-Geologische reeks 7: $129 \mathrm{pp}$.

Westermann, J.H. \& Zonneveld, J.I.S., 1956. Photo-geological observations and land capability $\&$ land use survey of the island of Bonaire. Koninklijk Instituut voor de Tropen (Amsterdam): 101 pp. 